\title{
DEVIASI FONOLOGIS TUTURAN BAHASA INDONESIA ANAK
}

\author{
oleh Bambang Yulianto \\ FBS Universitas Negeri Surabaya
}

\begin{abstract}
This article explains the phonological deviations in Indonesian utterances of children with the age range from 1.0 to 2.6, which represents a stage of language development with the children of the age range from 1.0 to 1.6 producing their first single-word utterances (SWU), those of the age range from 1.6 to 2.0 producing their first word combinations (FWC), and those of the age range from 2.0 to 2.6 producing their first simple and complex sentences (SCS). The data show that 11 phonological deviation patterns are found in SWU, 13 phonological deviation patterns are found in FWC, and 7 phonological deviation patterns are found in SCS. On the basis of these available patterns, it could be stated that (1) the most productive patterns are stopping, gliding, nasalizing, and cluster reduction, (2) the deviation patterns tend to decrease as age increases, (3) as children get older, the reduplication pattern is abandoned and the deletion pattern decreases, and (4) a lateralization pattern occurs when children begin producing SCS. Most of the patterns are universal since they also occur in the utterances of subjects of other researchers.
\end{abstract}

Keywords : patterns of phonological deviations, children utterances, underlying representation, phonetic representation, SWU, FWC, SCS

\section{A. PENDAhULUAN}

Tuturan anak pada awal perkembangannya memiliki keterbatasan, baik secara fonologis, semantis, struktur, maupun pragmatis. Sering terjadi pada orang lain (dewasa) kesulitan mengidentifikasi tuturan anak, seperti [dus] sebagai juice, [doti] sebagai doggi, atau [dot] sebagai coat atau dont tanpa bantuan konteks dan pengenalan terhadap anak itu (Clark \&Clark, 1977:387). Scollon (dalam Taylor, 1990:246) juga mencatat hal serupa. Kata boot dan ball diujarkan anak sebagai [bu] dan [bo]. Kata flower diucapkan sebagai [fa:uz]. Di samping itu, terdapat pula tuturan yang menunjukkan penghilangan suku kata yang tidak bertekanan (unstressed syllable), seperti banana yang diujarkan sebagai [nana] dan giraffe diujarkan sebagai [raf]. Kedaaan tersebut menunjukkan bahwa terdapat perbedaan fonologis antara tuturan anak dengan tuturan orang dewasa.
Hal di atas menunjukkan bahwa kemampuan berbahasa itu tidak diperoleh secara serentak sempurna, melainkan berkembang secara bertahap sejak masa kanakkanak hingga dewasa. Chomsky (1980:37) menggambarkan perkembangan itu dari $\mathrm{S}_{0}$ (initial zero state) melalui tahap-tahapan $\mathrm{S}_{1}, \mathrm{~S}_{2}$, ... yang akhirnya sampai pada $\mathrm{S}_{\mathrm{s}}$ (steady state).

Keadaan awal bahasa anak pada umumnya berisi penyederhanaanpenyederhanaan terhadap tuturan orang dewasa (Clark \& Clark, 1977:397). Penyederhanaan itu dapat berupa penyingkatan maupun penyesuaian fonologis sesuai dengan perkembangan kemampuan artikulatorisnya. Jika dibandingkan dengan tuturan orang dewasa, tuturan anak tersebut secara linguistis dianggap mengandung deviasi fonologis. Simanjuntak (1990b:72) menyebutnya sebagai fonologi yang menyimpang. Bahkan, Carrol (1986:320) menyebutnya dengan kesalahan 
fonologis (phonological error). Paivio \& Begg (1981:204) dan Garnham (1985:208) juga menyebutnya dengan kesalahan ujaran (speech error).

Deviasi fonologis dalam analisis fonologi generatif berada pada tataran representasi fonetis. Secara umum dalam fonologi generatif terdapat tiga komponen yang menjadi dasar analisisnya: (a) representasi dasar [RD], (b) kaidah-kaidah fonologis, dan (c) representasi fonetis [RF] (Dell, 1980:63). Proses fonologis pada dasarnya melewati dua tataran. Pertama, tataran tersirat (underlying form) yang disebut juga representasi fonologis. Bentuk tersirat ini berubah menjadi bentuk baru sebagai hasil suatu proses fonologis. Kedua, tataran tersurat (surface form), yaitu ujaran yang sesungguhnya yang kita dengar. Bentuk ini sering disebut RF. Dalam hal ini yang termasuk di dalamnya adalah tuturan anak yang berbeda dengan tuturan standar bahasa Indonesia (TSBI). TSBI inilah yang merupakan RD.

Dalam bentuk yang konkret rumus itu oleh Chomsky \& Halle (1968:332) serta Sommerstein (1977:142) merumuskan perubahan itu sebagai $\mathbf{A} \rightarrow \mathbf{B} / \mathbf{X}-\mathbf{Y}$, yang dibaca sebagai A menjadi $B$ dalam lingkungan di antara $X$ dan Y. Dalam hal ini A merupakan $\mathrm{RD}, \mathrm{B}$ adalah $\mathrm{RF}, \mathrm{X}$ merupakan bunyi yang mendahului $\mathrm{A}$, sedangkan $\mathrm{Y}$ adalah bunyi yang mengikuti A tersebut.

\section{B. KAJIAN TENTANG DEVIASI FONOLOGIS}

Studi tentang deviasi (penyimpangan) tuturan anak telah banyak dilakukan. Deviasi ada yang diklasifikasikan berdasarkan tinjauan tertentu. Fromkin (dalam Clark \& Clark, 1977: 274), misalnya, menggolongkan penyimpangan fonologis itu ke dalam tujuh kelompok, yaitu antisipasi (anticipation), persevaratori (perseveration), pembalikan (reversal), pemaduan (blend), haplologi (haplologi), salah penurunan (misderivation), dan penggantian kata (word substitution).

Antisipasi terjadi bila munculnya bunyi tertentu akibat diantisipasi (disesuaikan) oleh bunyi yang hadir di belakangnya, misalnya take my bike yang diujarkan menjadi [beik mai baik] 'bake my bike'. Perseveratori sejenis dengan antisipasi, namun pada perseveratori bunyi yang berperan berada di depan, misalnya pulled a tantrum yang diujarkan [puld ? pæntr?m] 'pulled a pantrum'. Pembalikan terjadi bila segmen tertentu dipertukarkan tempatnya dengan segmen lainnya dalam posisi yang sama, misalnya $\boldsymbol{K a t z}$ and Fodor yang diujarkan [fæts nd kodør] 'fats and kodor'. Pemaduan terjadi apabila dua kata disatukan dalam satu ujaran, seperti bentuk grizzly + ghasty menjadi [grstli] 'grastly'. Haplologi terjadi bila terdapat bagian kata atau frasa yang dihilangkan pada posisi tengahnya, misalnya Post Toasties menjadi Posties. Salah penurunan terjadi bila terdapat pembentukan kata yang tidak gramatikal dalam satuan sintaktis, misalnya in intervening node yang berubah menjadi an intervenient node.Penggantian terjadi bila terdapat kata tertentu yang diganti oleh kata lainnya, misalnya perubahan dari before the place opens menjadi before the place closes.

Paivio \& Begg (1981:205-206) mengelompokkan kesalahan ujaran berdasarkan klasifikasi Fromkin dan Garret. Dalam hal ini kesalahan ujaran dikelompokkan menjadi tiga macam, yaitu pertukaran (exchange), perubahan (shift), dan kesalahan lainnya. Pertukaran terjadi bila dua unit linguistik saling bertukar satu dengan lainnya. Pertukaran ini terjadi pada beberapa level produksi. Kesalahan yang paling terkenal dalam hal ini adalah apa yang disebut dengan spoonerism (disebut juga oonerspism), di mana kata-kata dan bagian-bagiannya saling bertukar. Misalnya, dear old queen diujarkan [kwir ould din] 'queer old dean'; bite your tongue diujarkan [tait yor ban] 'tight your bung'; clear blue sky diujarkan [glir plu skai] 'glear plue sky'; dan store close diujarkan [kolr stouz] 'clore stose'. Perubahan terjadi bila sebuah segmen suatu kata berubah dalam suatu urutan ujaran. Yang tergolong kelompok ini adalah antisipasi dan perseverasi. Contoh antisipasi adalah perubahan dari take my bike menjadi 
[beik mai baik] 'bake my bike'; sedangkan contoh persevarasi adalah perubahan dari take my bike menjadi [teik mai taik] 'take my tike' atau he gets it done menjadi he get its done. Kesalahan lainnya meliputi malapropism, haplologi, dan blend. Malapropism adalah menggunakan kata yang tidak tepat pada tempat yang semestinya (benar). Misalnya, fragrant menjadi flagrant; depreciate menjadi deprecate; dan delegate menjadi relegate. Haplologi merupakan penghilangan bagian kata atau frasa. Misalnya, probably menjadi probly; quarter to four menjadi quarta to four. Blend merupakan pemaduan dua kata menjadi satu. Misalnya, detest + desnity menjadi detestiny; semantics + syntax menjadi semantax.

Sementara itu, Garnham (1985:208) juga membedakan penyimpangan ujaran menjadi tujuh macam. Pengelompokannya mirip dengan yang dilakukan oleh Fromkin maupun Paivio \& Begg di atas. Ketujuh penyimpangan ujaran itu adalah sebagai berikut: antisipasi (anticipation), misalnya the new Mel Brooks film diujarkan [ð? nyu bel bruks f?lm] 'the new Bel Brooks film'; penerusan/ perseverasi (perseveration), misalnya practical class diujarkan [prktik?1 kras] 'practical crass'; pengurangan (omission), misalnya British diujarkan [brits] 'Britsh'; penambahan (addition), misalnya better off than diujarkan [bet?r of wais ðæn] 'better off wise than'; pertukaran (exchange), misalnya on a table around you diujarkan [raund? teibl on $\mathrm{yu}$; ' 'round a table on you'; penggantian/ substitusi (substitution), misalnya shed burnt diujarkan [ $\varepsilon \varepsilon \mathrm{d}$ b?rst] 'shed burst'; dan percampuran/ pemaduan (blend), misalnya hilaraty + hysterics diujarkan [hil?rIks] 'hilarics'.

Berkaitan dengan hal ini, Taylor (1990:197) menunjukkan empat tipe umum kesalahan yang menyangkut bunyi ujaran, yaitu substitusi (substitution), penambahan (addition), perubahan (shift), dan pelesapan (delition). Keempat tipe kesalahan ujaran itu adalah sebagai berikut. Substitusi (subtitution) meliputi pertukaran (exchange), antisipatori (anticipatory), dan perseveratori (perseveratory). Yang termasuk pertukaran adalah key chain yang diujarkan sebagai [cei kein] 'chee cane'; clear blue yang diujarkan sebagai [ji?r plu] 'gear plue'. Contoh antisipatori adalah reading list yang diujarkan sebagai [lidIn rIst] 'leading rist'. Sedangkan, contoh perseratori adalah beef noodle yang diujarkan sebagai [bi:f nidl] 'beef needle'. Penambahan (addition) meliputi antisipatori dan persevaratori. Yang termasuk antisipatori adalah eerie stamp yang diujarkan sebagai [stiri stmp] 'steerie stamp'. Sedangkan blue bug yang diujarkan sebagai [blu blak] 'blue blug' merupakan contoh kesalahan perseveratori. Perubahan (shift) terjadi pada black boxes yang diujarkan [bæk blokses] 'back bloxes'. Penghilangan (delition) terjadi pada same state yang diujarkan [sem set] 'same sate'.

Carroll (1986:320) juga hanya mengategorikan kesalahan ke dalam empat pola, yaitu kesalahan reduksi (reduction error), kesalahan pemaduan (coalescence error), kesalahan asimilatif (assimilative error), dan kesalahan reduplikasi (reduplication error). Kesalahan reduksi (reduction error) adalah kesalahan akibat adanya segmen yang direduksikan, misalnya hurt yang diujarkan [?rt] 'urt' dan behind yang diujarkan [aind] 'ind'. Kesalahan pemaduan (coalescence error) adalah kesalahan akibat adanya beberapa segmen dalam urutan yang berbeda dipadukan sehingga terdapat segmen yang ditanggalkan, misalnya pacifier diujarkan menjadi [paf] 'paf'. Kesalahan asimilatif (assimilative error) adalah kesalahan akibat adanya segmen tertentu yang diasimilasi, baik oleh segmen di depan maupun di belakangnya, seperti kiss diujarkan [gIk] 'gik', rubberband diujarkan [bababar] 'bubbabar'. Kesalahan reduplikasi (reduplication error) adalah kesalahan ujaran akibat adanya suku kata tertentu yang direduplikasikan, misalnya kitty yang diujarkan [titi] 'titty'.

Sementara itu, Clark \& Clark (1977: 397-400) sendiri mengelompokkan penyimpangan fonologis itu ke dalam empat macam, yaitu penghilangan segmen akhir, 
reduksi konsonan pada kluster, penghilangan suku kata takbertekanan, dan reduplikasi suku kata. Penghilangan segmen akhir (ommission of final segment), misalnya pipe, kick, dan boot, yang masing-masing diujarkan menjadi [pai], [ki], dan [bu]. Reduksi konsonan pada kluster (reduction of consonant cluster), seperti small, slide, dan clock, yang masing-masing diujarkan [mo], [lid], dan [gok]. Penghilangan suku kata takbertekanan (ommission of unstressed syllables), misalnya kata away yang bertekanan pada suku ultima (suku kedua) diujarkan [we] dan kata tomato, yang bertekanan pada suku kata penultima (suku kedua dari akhir), diujarkan [mdo]. Reduplikasi suku kata (reduplication), misalnya pada kata kitchen suku kata [ki] direduplikasikan menjadi [kiki] dan kata daddy diucapkan menjadi [dd].

Jika diperhatikan beberapa pemolaan kesalahan ujaran yang dipaparkan di atas, tampak agak bervariasi. Ada pemolaan yang tidak semata-mata didasarkan pada penyimpangan fonologis, seperti yang dilakukan oleh Fromkin dengan adanya blend, misderivation, dan word substitution, Garnham dengan adanya addition dan blend, dan juga oleh Paivio dengan adanya blend. Hal itu lebih mengarah kepada penyimpangan pembentukan kata atau kalimat, yang lebih bersifat gramatikal. Sedangkan, pemolaan yang dilakukan oleh Carroll dan Clark \& Clark lebih komprehensif untuk penyimpangan secara fonologis.

\section{POLA DEVIASI FONOLOGIS TUTURAN BI ANAK}

Yulianto (2001:4849), dengan mendasarkan klasifikasi Ingram (1992:2) dalam penelitiannya tentang perkembangan tuturan bahasa Indonesia anak usia 1;02;6, membagi tahapan perkembangan atas tiga kelompok, yaitu (a) tahap kalimat kata tunggal (TKT), yang terjadi pada anak usia 1;01;6, (b) tahap kalimat kombinasi kata (TKK) yang berlangsung pada usia 1;62;0, dan (c) tahap kalimat sederhana dan kompleks (TKS), yang berlangsung pada usia 2;02;6. Ketiga tahapan tersebut akan digunakan untuk memetakan pola deviasi fonologis pada anak.

\section{Pola Deviasi Fonologis Tuturan BI Anak pada TKT}

Pada tahap TKT Yulianto (2001:171) mencatat bahwa anak telah menghasilkan 64 kata. Kata-kata itu berhubungan dengan kehidupan sehari-hari anak, yakni aktivitas, keadaan, dan nama-nama benda sekitar. Dari 64 kata yang diproduksi diketahui terdapat lima belas konsonan, yakni /m/,/p/, /?/,/t/, /h/,/n/, $/ \mathrm{b} /, / \mathrm{d} /, / \mathrm{y} /, / \mathrm{y} /, / \breve{c} /, / \mathrm{j} /, / \mathrm{w} /, / \mathrm{k} /$, dan $/ \mathrm{g} /$. Seluruh vokal yang ada dalam TSBI telah dikuasai dengan sempurna pada tahap ini, yakni /a/, /i/, /u/,/e/,/o/, dan // serta alofonnya, yakni [I], [U], $[\varepsilon]$, dan [o].

Ada empat pola deviasi fonologis tuturan bahasa Indonesia (BI) anak pada tahap TKT, pola penggantian, pola penghilangan, pola asimilasi, dan pola reduplikasi (Yulianto, 2001:423433).

\section{a. Pola Penggantian}

Yang termasuk dalam pola penggantian adalah tuturan (RF) yang di dalamnya terkandung bunyi tertentu, yang dihasilkan dari proses menggantikan bunyi yang lainnya di dalam RD. Dalam pola ini terangkum pola penghambatan, pengedepanan, peluncuran, dan penasalan.

\section{1) Penghambatan}

Dææm polæ ini konsonæn frikæif, seperti /s/, /z/, /f/ RD digænti dengæn konsonæn stop/hæmbæ dæam RF-nyæ Konsonæn /s/ dædæm RD diubæh menjædi konsonæn hæmbæ/t/ ææaupun /č/. Konsonæn /z/ dadæm RD diubæh menjædi konsonæn hæmbæ // ataupun /j/. Konsonan frikatif /f/ juga diubah menjadi konsonan hambat/p/ di dalam RF-nya.

Contoh:

$\begin{array}{llll}{[\mathrm{b} ? \mathrm{so}]} & \rightarrow[\text { to }] & {[\mathrm{mas}]} & \rightarrow[\text { mat }] \\ {[\varepsilon \mathbf{s}]} & \rightarrow[\varepsilon \mathrm{t}] & {[\mathrm{pus}]} & \rightarrow[\text { put }] \\ {[\text { susu }]} & \rightarrow[\text { čuču }] & {[\mathrm{iza}]} & \rightarrow[\text { da }]\end{array}$


[iza $] \quad \rightarrow[\mathbf{j} \mathbf{j}] \quad[$ tifi $] \rightarrow[$ pi $]$

\section{2) Pengedapanan}

Dalam pola ini konsonan yang berfitur +belakang diganti dengan konsonan belakang. Konsonan $/ \mathrm{k} /, / \mathrm{g} /$, dan $/ \mathrm{y} / \mathrm{yang}$ +belakang berubah menjadi konsonan homorgannya, yakni $/ \mathrm{t} /, / \mathrm{d} /$, dan $/ \mathrm{n} /$, yang berfitur belakang.

Contoh:

$\begin{array}{llll}{[\mathrm{kakUy}]} & \rightarrow[\mathrm{tUn}] & {[\mathrm{kkUn}]} & \rightarrow[\mathrm{t} U \mathrm{t}] \\ {[\mathrm{p} \text { ?rgi }]} & \rightarrow[\text { di }] & {[\text { bonek }]} & \rightarrow \text { [ta }]\end{array}$

\section{3) Peluncuran}

Yang termasuk dalam pola ini adalah kata-kata yang di dalamnya terdapat bunyi luncur yang berasal dari penggantian bunyi likuid. Dalam hal ini bunyi likuid /r/ dan /1/ diganti menjadi bunyi luncur/y/. Penggantian bunyi likuid tersebut terjadi pada posisi awal suku.

Contoh:

$\begin{array}{llll}{[\text { burUn] }} & \rightarrow[\text { yUn] } & {[\text { merah }]} & \rightarrow[\text { yah }] \\ \text { [t?IUr }] & \rightarrow \text { yUn, }] & {[\text { b?li }} & \rightarrow[\text { yi }] \\ \text { [tulIs }] & \rightarrow \text { ylt }] & {[\text { lari }]} & \rightarrow \text { [yayi }]\end{array}$

\section{4) Penasalan}

Dalam pola ini konsonan likuid /r/ dan

/1/ RD diganti menjadi kon-sonan nasal /n/ dalam RF-nya. Konsonan yang dinasalkan itu adalah konsonan likuid yang berada pada posisi final.

Contoh:

\begin{tabular}{|c|c|c|}
\hline [bubUr] & $\rightarrow[b U n]$ & {$[\mathrm{t} ? 1 \mathrm{U} \mathbf{r}]$} \\
\hline [mobIl] & $\rightarrow[\mathrm{bIn}]$ & [sandal] \\
\hline
\end{tabular}

\section{b. Pola Penghilangan}

Apabila terdapat kata yang bunyibunyi tertentunya ditengarai dalam RD tidak muncul dalam RF-nya, kata tersebut termasuk dalam kategori pola penghilangan. Yang termasuk ke dalam pola ini adalah pola penghilangan suku takbertekanan, penghilang- an konsonan awal, penghilangan konsonan akhir, dan pereduksian kluster/deret konsonan.

\section{1) Penghilangan Suku Kata Takbertekanan}

Yang termasuk dalam pola ini adalah kata-kata ekasuku yang dite-ngarai berasal dari kata dwisuku atau trisuku (RD). Suku kata yang tidak muncul dalam tuturan itu adalah suku takbertekanan. Dalam TSBI suku kata yang takbertekanan pada umumnya terdapat pada suku pertama dalam kata dwisuku atau suku pertama dan kedua dalam kata yang trisuku.

Contoh:

\begin{tabular}{|c|c|c|}
\hline [mama] & $\rightarrow[\mathrm{ma}]$ & [mimi?] \\
\hline [roti] & $\rightarrow \mathrm{t} i$ & [p?rgi] \\
\hline [bubUr] & $\rightarrow[b U n]$ & [buka?] \\
\hline [mobIl] & $\rightarrow[\mathrm{bIn}]$ & [krupU?] \\
\hline [nasi?] & $\rightarrow$ [čin] & [boneka] \\
\hline
\end{tabular}

\section{2) Penghilangan Konsonan Awal}

Yang termasuk ke dalam pola ini adalah kata-kata yang ditengarai berasal dari kata (RD) yang telah dihilangkan konsonan awalnya. Contoh:

\begin{tabular}{|c|c|c|c|}
\hline [mandi] & $\rightarrow[$ ṇi $]$ & [mimi?] & $\rightarrow$ imi?] \\
\hline [mobIl] & $\rightarrow$ [obIn, $]$ & [gendəy] & $\rightarrow$ [eņað口] \\
\hline [b?li] & [?yi] & {$[\mathbf{s} ? \mathrm{mUt}]$} & $\rightarrow[? \mathrm{mUt}]$ \\
\hline [baju] & $\rightarrow$ aju] & [duwa] & $\rightarrow$ unwa] \\
\hline
\end{tabular}

\section{3) Penghilangan Konsonan Akhir}

Yang termasuk ke dalam pola ini adalah kata yang ditengarai berasal dari kata (RD) yang telah dihilangkan konsonan finalnya.

Contoh:

$[\mathrm{p} ? \mathrm{rm} \varepsilon \mathbf{n}] \rightarrow[\mathrm{m} \varepsilon]$

\section{4) Pereduksian Kluster/Deret Konsonan}

Pola ini melingkupi kata-kata yang ditengarai berasal dari RD yang kluster atau deret konsonannya telah direduksi, sehingga menjadi konsonan tunggal. Pereduksian pada kluster terjadi dengan menghilangkan 
konsonan yang kedua, sedangkan pereduksian pada deret konsonan terjadi dengan menghilangkan konsonan yang pertama.

Contoh:

$\begin{array}{llll}{[\text { putri }]} & \rightarrow \text { ti }] & {[\mathrm{ba} \text { ?so }]} & \rightarrow \text { ato }] \\ {[\text { p?rgi }]} & \rightarrow[\text { ?di }] & {[\mathrm{k} \text { ?rja }]} & \rightarrow[\text { ?ja }]\end{array}$

\section{c. Pola Asimilasi}

Dalam pola ini terjadi penyesuaianpenyesuaian suatu bunyi terhadap bunyi yang lainnya, baik yang mendahului maupun yang mengikutinya. Bunyi-bunyi yang bersesuaian tersebut dapat berupa bunyi vokal maupun konsonan. Yang termasuk dalam pola asimilasi dalam TKT ini adalah nasalisasi dan harmonisasi vokal.

\section{1) Nasalisasi}

Dalam pola ini kata-kata ekasuku yang dihasilkan ditengarai berasal dari kata dwisuku (RD) yang telah dihilangkan suku takbertekanannya, tetapi konsonan final suku yang dihilangkan itu tidak ikut dihilangkan karena konsonan itu diasimilasi secara regresif oleh konsonan awal suku yang muncul tersebut. Konsonan yang diasimilasi itu adalah konsonan nasal karena merupakan konsonan yang homorgan dengan konsonan hambat yang mengasimilasinya.

Di samping itu, terdapat pula kata dwisuku yang ditengarai berasal dari kata yang telah mengalami penghilangan konsonan awalnya. Dalam hal ini asimilasi terjadi dengan cara yang sama.

Contoh:

$$
\begin{array}{llll}
\text { [minta?] } & \rightarrow \text { [nta? }] & \text { [mandi] } & \rightarrow \text { [ndi] } \\
\text { [tinda?] } & \rightarrow \text { [nda? }] & \text { [gendoy }] & \rightarrow \text { [endoy }]
\end{array}
$$

\section{2) Harmonisasi Vokal}

Dalam pola ini suatu vokal disesuaikan menjadi vokal yang lain, yang sama dengan vokal tersebut. Pada kata ekasuku data 1002 ditengarai berasal dari kata dwisuku (RD) yang sebelum dihilangkan suku takbertekanannya terjadi harmonisasi vokal terlebih dahulu.

Contoh: $[$ maæm $] \rightarrow[$ maam $] \rightarrow$ amm $]$

\section{d. Pola Reduplikasi}

Dalam pola ini dihasilkan kata-kata dwisuku, yang struktur suku-sukunya adalah KV. Struktur suku tersebut diisi oleh konsonan dan vokal yang sama. Sebelum peristiwa reduplikasi, terjadi penghilangan suku awal terlebih dahulu pada kata dwisuku, sehingga dari proses itu dihasilkan kata ekasuku. Kata ekasuku inilah yang direduplikasi dengan mempertahankan pola KV tersebut.

Contoh:

$\begin{array}{lll}{[\text { mama }]} & \rightarrow[\text { ma }] & \rightarrow \text { mama }] \\ {[\text { bubUr }]} & \rightarrow \text { bUnn }] & \rightarrow \text { bubUn }]\end{array}$

\section{Pola Deviasi Fonologis Tuturan BI Anak pada TKK}

Pada tahap ini anak telah memperoleh 299 kata dengan jumlah konsonan yang dikuasainya mencapai 18 dan vokal beserta alofonnya mencapai 10. Ketiga konsonan yang baru dikuasai adalah /ñ /, /s/, dan /1/. Sementara itu, konsonan $/ \mathrm{k} /$ dan $/ \mathrm{g} /$ telah mantap dikuasai pada tahap ini. Bunyi diftong belum dikuasainya.

Pola deviasi fonologis yang terjadi pada TKK ini hanya terdiri atas tiga kategori, yaitu pola penggantian, pola penghilangan, dan pola asimilasi. Meskipun demikian, jumlah pola unsur-unsur kategori pada TKK ini lebih banyak bila dibandingkan dengan yang terjadi pada TKT. Pada tahap ini pola reduplikasi tidak muncul.

Berikut ini hanya dipaparkan beberapa pola deviasi baru yang belum muncul pada TKT.

\section{a. Pola Penggantian}

Di samping ditemukan pola penghambatan, pengedepanan, peluncuran, dan penasalan, seperti yang terjadi pada TKT, pada tahap ini terjadi deviasi fonologis dengan pola monoftongisasi. Pada pola ini bunyi diftong RD diganti menjadi bunyi monoftong pada RF. 
Dalam data terlihat bunyi monoftong // sebagai RF menggantikan diftong/ay/sebagai RD-nya.

Contoh:

[ramay $\rightarrow[$ ram $\varepsilon]$

\section{b. Pola Penghilangan}

Ada lima pola penghilangan pada tahap ini, yakni pola penghilangan suku takbertekanan, penghilangan konsonan awal, penghilangan konsonan akhir, pereduksian kluster/deret konsonan, dan pola haplologi. Dari kelimanya, hanya pola haplologi yang tidak ditemukan pada TKT. Pada pola haplologi, bunyi yang hilang pada kata-kata tertentu berada di tengah. Pada umumnya bunyi yang dihilangkan berstruktur VK.

Contoh:

[b?lakay] $\rightarrow$ bakan] [t?lina] $\rightarrow$ tina]

[doraemon] $\rightarrow$-daemon] [k?luwar] $\rightarrow$ kuwan]

\section{c. Pola Asimilasi}

Pada tahap ini ditemukan tiga macam subpola, yakni nasalisasi, harmonisasi vokal, dan harmonisasi konsonan. Kedua subpola yang pertama telah terjadi pada TKT. Harmonisasi konsonan terjadi dengan cara konsonan awal suku kedua kata dwisuku mengasimilasi konsonan awal suku pertama. Akibatnya, konsonan yang diasimilasi itu berubah menjadi seperti konsonan yang mengasimilasi.

Contoh:

[satu $] \rightarrow[$ tatu $] \quad[$ kuñči $] \rightarrow[$ čuñči $]$

\section{Pola Deviasi Fonologis Tuturan BI Anak pada TKS}

Jumlah konsonan yang dikuasai anak pada tahap ini belum berubah bila dibandingkan dengan tahap sebelumnya, yakni delapan belas konsonan. Namun, perkembangan luar biasa yang terjadi adalah pada penguasaan leksikon. Pada tahap ini anak telah menguasai 535 kata. Jumlah vokal juga bertambah dengan adanya penguasaan diftong/aw/dan/ay/.
Pada TSK ini pola deviasi fonologis yang ditemukan hanya terdiri atas dua kategori. Jika pada TKK pola asimilasi masih terjadi, sedangkan pola reduplikasi suka kaa tidak muncul, pada TSK ini keduanya telah tidak terjadi lagi. Kedua pola deviasi fonologis yang ada pada tahap ini adalah pola penggantian dan pola penghilangan.

\section{a. Pola Penggantian}

Pola penggantian pada TSK ini ada lima macam: pola penghambatan, peluncuran, penasalan, monoftongisasi, dan lateralisasi. Pola pengedepanan sudah tidak muncul lagi. Hal itu menunjukkan bahwa anak telah menguasai dengan sempurna konsonan +belakang. Pola lateralisasi baru muncul pada tahap ini karena anak telah menguasai bunyi lateral [1] untuk menganti likuid [r], yang memamng belum dikuasainya. Pada tahap sebelumnya likuid $[\mathrm{r}]$ ini diganti dengan bunyi luncur [y].

Pada pola lateralisasi, konsonan likuid /r/ RD, yang bercirikan bukan lateral berubah menjadi bunyi lateral /1/ pada RF-nya, , baik pada posisi awal suku maupun final.

Contoh:

$$
\begin{aligned}
& \text { [jarU?] } \rightarrow \text { ji?U?] [matahari] } \rightarrow \text { [matahali] } \\
& \text { [bibIr] } \rightarrow \text { bbibIl }] \text { [bočor }] \rightarrow \text { bočsl }]
\end{aligned}
$$

\section{b. Pola Penghilangan}

Pada tahap ini telah tidak ditemukan lagi pola penghilangan suku takbertekanan, penghilangan konsonan awal, dan penghilangan konsonan akhir. Kenyataan tersebut menunjukkan bahwa ucapan anak banyak yang mendekati sempurna sebagaimana TSBI.

Ada dua pola yang masih ditemukan, sebagaimana yang terjadi pada TKK, yaitu pola pereduksian kluster/deret konsonan dan pola haplologi. Namun, karena tidak ditemukan pola baru yang berbeda dengan pola sebelumnya, contoh keduanya tidak dipaparkan lagi di sini.

Seluruh pola deviasi fonologis yang terjadi dalam tiga tahap perkembangan bahasa tersebut dapat dinyatakan dalam Tabel 1 berikut. 
Tabel 1 Pola Deviasi Fonologis Tuturan Bahasa Indonesia Anak*

\begin{tabular}{|c|c|}
\hline Pola Deviasi Fonologis & Contoh \\
\hline $\begin{array}{l}\text { 1. Pola Penggantian } \\
\text { a. penghambatan } \\
\text { b. pengedepanan }{ }^{4} \\
\text { c. peluncuran } \\
\text { d. penasalan } \\
\text { e. monoftongisasi }{ }^{5} \\
\text { f. lateralisasi }\end{array}$ & 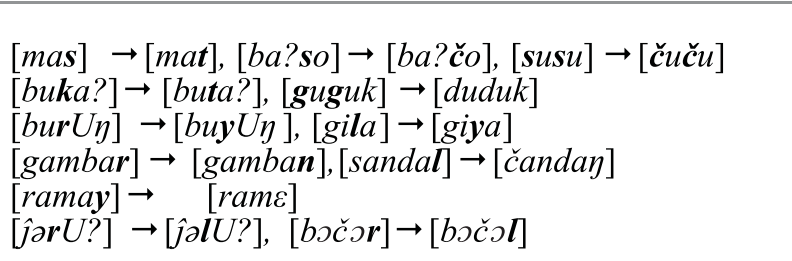 \\
\hline $\begin{array}{l}\text { 2. Pola Penghilangan } \\
\text { a. penghilangan suku takbertekanan } \\
\text { b. penghilangan konsonan awal } \\
\text { c. penghilangan konsonan akhir } \\
\text { d. pereduksian kluster/ } \\
\text { deret konsonan } \\
\text { e. haplologi }\end{array}$ & 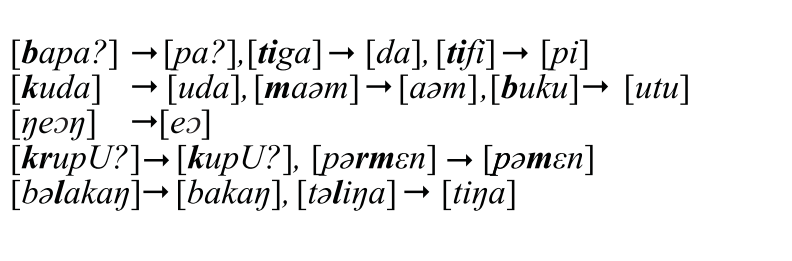 \\
\hline $\begin{array}{l}\text { 3. Pola Asimilasi } \\
\text { a. nasalisasi }{ }^{4} \\
\text { b. harmonisasi vokal }{ }^{4} \\
\text { c. harmonisasi konsonan }{ }^{2}\end{array}$ & 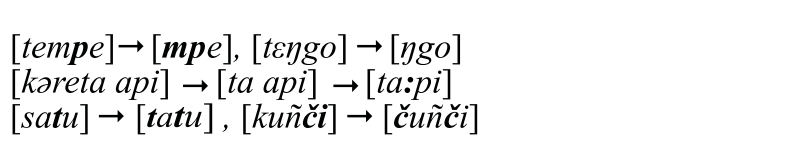 \\
\hline 4. Pola Reduplikasi ${ }^{1}$ & {$[m a m a] \rightarrow[\boldsymbol{m a}] \rightarrow[$ mama $],[$ bubUr $] \rightarrow[\boldsymbol{b} \boldsymbol{U} \boldsymbol{n}] \rightarrow[\boldsymbol{b u b} \boldsymbol{U} \boldsymbol{n}]$} \\
\hline
\end{tabular}

Keterangan:

*berlangsung hingga usia 2;5(26) atau akhir periode TSK ${ }^{1}$ pola ini hanya terjadi pada TKT ${ }^{2}$ pola ini hanya terjadi pada TKK ${ }^{3}$ pola ini hanya terjadi pada TSK ${ }^{4}$ pola ini hanya terjadi pada TKT dan TKK ${ }^{5}$ pola ini hanya terjadi pada TKK dan TSK

\section{PEMBAHASAN}

\section{Pola Deviasi Fonologis dan Perkembangan Tuturan}

Berdasarkan paparan yang ada dapat disimpulkan hal-hal berikut. Pertama, hingga akhir periode TSK pola deviasi fonologis yang paling produktif adalah pola penghambatan, peluncuran, penasalan, dan pereduksian kluster/deret konsonan. Keempat pola ini selalu terjadi pada setiap tahap perkembangan bahasa. Hal ini disebabkan konsonan frikatif /f/, likuid $/ \mathrm{r} /$, dan kluster hingga usia usia anak mencapai 2;6 belum mampu diproduksi.

Kedua, terlihat kecenderungan bahwa jumlah pola deviasi fonologis semakin berkurang sejalan dengan bertambahnya usia anak. Hal ini dapat diamati dengan adanya hanya 7 pola pada TSK, yang pada TKT mencapai 11 pola dan TKK 13 pola. Peningkatan jumlah pola dari TKT ke TKK lebih banyak ditentukan oleh faktor jumlah data
TKK yang lebih banyak daripada data pada TKT.

Ketiga, semakin bertambah usia S, pola reduplikasi mulai ditinggalkan. Hal itu terlihat pada adanya pola yang ditemukan pada TKT tersebut tidak ditemukan lagi pada TKK dan TSK. Pola reduplikasi ini disinyalir merupakan kelanjutan dari proses serupa yang terjadi pada tahap pralinguistik.

Keempat, adanya kecenderungan kategori pola penghilangan semakin berkurang seiring dengan bertambahnya usia anak. Hal itu terlihat dengan adanya pola penghilangan suku takbertekanan, penghilangan konsonan awal, dan penghilangan konsonan akhir yang masih terjadi pada TKT dan TKK, namun pada TSK sudah tidak terjadi lagi. Hal itu sejalan dengan pernyataan sebelumnya, yakni bahwa semakin bertambah usia, semakin banyak ucapan kata yang sempurna sesuai dengan TSBI.

Kelima, pola lateralisasi merupakan 
pola yang paling sulit dihasilkan selama tiga tahap perkembangan bahasa. Dalam data, pola ini baru muncul pada TSK. Hal itu disebabkan adanya data bahwa pada tahap-tahap sebelumnya konsonan likuid yang lateral belum dihasilkan.

\section{Keuniversalan}

Data mengenai deviasi fonologis yang terjadi pada Mara (subjek penelitian Raja,
1998), Echa (subjek penelitian Dardjowidjojo, 2000), dan Amahl (subjek penelitian Smith, 1973) secara khusus tidak dipaparkan. Namun, karena pola deviasi fonologis didasarkan kepada proses-proses fonologis yang ada, data penelitian ketiga subjek tersebut masih dapat dikaitkan dengan S (subjek penelitian Yulianto, 2001). Hasilnya dapat dipaparkan dalam Tabel 2 yang berikut.

Tabel 2 Pola Deviasi Fonologis pada S, Mara, Echa, dan Amahl

\begin{tabular}{|c|c|c|c|c|}
\hline Pola Deviasi Fonologis & $\mathrm{S}$ & Mara & Echa & Amahl \\
\hline \multicolumn{5}{|l|}{ 1. Pola Penggantian } \\
\hline a. penghambatan & $\mathrm{V}$ & $\mathrm{V}$ & $\mathrm{V}$ & $\mathrm{V}$ \\
\hline b. pengedepanan & $\mathrm{V}$ & $\mathrm{V}$ & $\mathrm{V}$ & $\mathrm{V}$ \\
\hline c. peluncuran & $\mathrm{V}$ & $\mathrm{V}$ & - & $\mathrm{V}$ \\
\hline d. penasalan & $\mathrm{V}$ & $\mathrm{V}$ & - & - \\
\hline e. monoftongisasi & $\mathrm{V}$ & $\mathrm{V}$ & $\mathrm{V}$ & - \\
\hline f. lateralisasi & $\mathrm{V}$ & $\mathrm{V}$ & V & $\mathrm{V}$ \\
\hline \multicolumn{5}{|l|}{ 2. Pola Penghilangan } \\
\hline a.penghilangan suku takbertekanan & $\mathrm{V}$ & $\mathrm{V}$ & $\mathrm{V}$ & $\mathrm{V}$ \\
\hline b. penghilangan konsonan awal & $\mathrm{V}$ & $\mathrm{V}$ & $\mathrm{V}$ & $\mathrm{V}$ \\
\hline c. penghilangan konsonan akhir & $\mathrm{V}$ & $\mathrm{V}$ & $\mathrm{V}$ & $\mathrm{V}$ \\
\hline d.pereduksian kluster/deret konsonan & $\mathrm{V}$ & $\mathrm{V}$ & $\mathrm{V}$ & $\mathrm{V}$ \\
\hline e. haplologi & $\mathrm{V}$ & $\mathrm{V}$ & - & $\mathrm{V}$ \\
\hline \multicolumn{5}{|l|}{ 3. Pola Asimilasi } \\
\hline a. nasalisasi & $\mathrm{V}$ & $\mathrm{V}$ & $\mathrm{V}$ & $\mathrm{V}$ \\
\hline b. harmonisasi vokal & $\mathrm{V}$ & $\mathrm{V}$ & $\mathrm{V}$ & $\mathrm{V}$ \\
\hline c. harmonisasi konsonan & $\mathrm{V}$ & $\mathrm{V}$ & $\mathrm{V}$ & $\mathrm{V}$ \\
\hline 4. Pola Reduplikasi & $\mathrm{V}$ & $\mathrm{V}$ & - & - \\
\hline
\end{tabular}

Berdasarkan Tabel 2 di atas terungkap pola deviasi fonologis yang terjadi pada $\mathrm{S}$ juga terjadi pada Mara. Pada Echa sebagian besar pola deviasi itu hampir sama. Dalam hal ini pola penasalan dan peluncuran tidak terjadi pada Echa. Sebenarnya, kedua pola itu terjadi dari bunyi likuid. Padahal, pola deviasi yang menyangkut bunyi likuid ada tiga macam, yakni pola penasalan, peluncuran, dan lateralisasi. Yang terjadi pada Echa adalah pola lateralisasi karena Echa telah menghasilkan konsonan lateral $/ 1 /$.

Pola umum penghilangan hampir semua yang terjadi pada $\mathrm{S}$ juga terjadi pada
Echa, kecuali haplologi. Sayang, tidak ada data yang cukup mengenai hal ini pada penelitian Dardjowidjojo (2000). Namun, dapat diprediksikan hal yang demikian kemungkinan besar terjadi pada Echa mengingat hal serupa terjadi pada Mara dan bahkan pada Amahl, yang menggunakan bahasa ibu bahasa Inggris.

Pola asimilasi lebih bersifat universal daripada yang lain karena pada semua anak terlihat pola ini, sedangkan reduplikasi hanya terjadi pada S dan Mara. Hal ini disebabkan oleh munculnya pola tersebut pada usia yang agak dini. Pola reduplikasi ini disinyalir merupakan kelanjutan dari tahap pralinguistik. 
Pada Amahl pola penasalan tidak terjadi karena memang dalam bahasa Inggris konsonan $/ \mathrm{r} /$ pada posisi final sangat terbatas, sedangkan konsonan /1/ telah dikuasainya. Data mengenai monoftongisasi dan reduplikasi tidak terlihat. Sebagaimana diungkapkan sebelumnya, pola reduplikasi ini lebih banyak merupakan perkembangan lanjutan dari tahap pralinguistik. Padahal, Amahl mulai diambil datanya pada usia $2 ; 2$.

\section{E. PENUTUP}

Berdasarkan uraian di depan terungkap bahwa terlihat kecenderungan jumlah pola deviasi fonologis pada tuturan anak semakin berkurang; pola reduplikasi mulai ditinggalkan; dan pola penghilangan semakin berkurang sejalan dengan bertambahnya usia anak. Hal itu semua memperkuat pernyataan sebelumnya bahwa ujaran anak semakin lama semakin sempurna karena jumlah penyimpangan fonologisnya semakin berkurang.

Pola deviasi fonologis itu pun bersifat universal, meskipun terdapat sedikit variasi.

\section{DAFTAR PUSTAKA}

Carroll, David W. 1986. Psychology of Language. Belmont: Wadsworth, Inc.

Chomsky, Noam. 1980. On Cognitive Structures and Their Development. Dalam Palmarini, M. Piattelli (Ed.). 1980. The Debate between Jean Piaget and Noam Chomsky. London: Routledge and Kegan Paul.

Chomsky, Noam \& M. Halle. 1968. The Sound Pattern of English. New York: Harper \& Row.
Clark, H.H. \& E. Clark. 1977. Psychology and Language: An Introduction to Psycholinguistics. New York: Harcourt Brace Jovanovich, Inc.

Dardjowidjojo, Sunjono. 2000. Echa: Kisah Pemerolehan Bahasa Anak Indo-nesia. Jakarta: Grasindo.

Dell, Francois. 1980. Generative Phonology. Cambridge: Cambridge Univer-sity Press.

Garnham, Alan. 1985. Psycholinguistics: Central Topics. London: Methuen.

Ingram, David. 1992. First language Acquisition: Method, Description, and Explanation. Cambridge: Cambridge University Press.

Paivio, Allan and Begg, Ian. 1981. Psychology of Language. Englewood Cliffs: Prentice-Hall, Inc.

Simanjuntak, Mangantar. 1990. Teori Fitur Distingtif dalam Fonologi Gene-ratif: Perkembangan dan Penerapannya. Jakarta: Gaya Media Pratama.

Smith, Neilson V. 1973. The Acquisition of Phonology: A Case Study. Cambridge: Cambridge University Press.

Sommerstein, A.H. 1977. Modern Phonology. Baltimore: Univ. Park Press.

Taylor, Insup. 1990. Psycholinguistics: Learning and Using Language. Englewood Cliffs: Prentice-Hall International, Inc.

Yulianto, Bambang. 2001. Perkembangan Fonologis Tuturan Bahasa Indonesia Anak: Suatu Tinjauan Berdasarkan Fonologi Generatif. Disertasi Tidak Diterbitkan. Malang: PPs Universitas Negeri Malang. 